\title{
Natural regime of streamflow trends in Macedonia
}

\author{
IVAN RADEVSKI, SVEMIR GORIN, MILENA TALESKA, OLGICA DIMITROVSKA
}

Ss. Cyril and Methodius University, Faculty of Natural Sciences and Mathematics, Department of Geography, Macedonia; e-mail: radevskiivan3@gmail.com

ABSTRACT This study investigates the annual and seasonal trends of minimum, mean and maximum streamflow, analyzed on 13 gauges/streams with natural regime, predominantly mountainous and homogeneously distributed in the studied area. The varying period of at least 40 years is used in the analysis. After the pre-whitening TFPW method was applied, the Mann-Kendall and Sen's slope tests were used for trend testing. The analysis detects significant decreasing trends in the country (according to $\mathrm{a}=0.1$ significance level). In general, the streamflow shows levels of decrease in almost all streams with lower or higher magnitude (from 0.1 to 0.01 ). The results provide a unique assessment of streamflow trends in the country and the current findings are consistent with those in other regions of Europe, especially in Southern Europe. Significant trends of decrease have been found in each of the 13 streamflow gauges throughout Macedonia without a single positive significant trend. The test confirmed the general decreasing streamflow trend in the country; even the stations without any significant decreasing results are generally heading downward.

KEY WORDS Macedonia - hydrology - streamflow - trends - Mann-Kendall - Sen's test

RADEVSKI, I., GORIN, S., TALESKA, M., DIMITROvSKA, O. (2018): Natural regime of streamflow trends in Macedonia. Geografie, 123, 1, 1-20.

Received June 2017, accepted January 2018.

CC Česká geografická společnost, z. s., 2018 


\section{Introduction}

One of the significant parameters for estimating the global water changes in connection with the climate change is the river streamflow, besides the pure climatology studies of the temperature and precipitation changes. This work aims to belong to the numerous studies of streamflow trend research so it can obtain a wider perception of the streamflow trends. It is of great significant value, especially for the country with reduced instrumental and measurement condition to choose undisturbed natural regime stream gauges with time series without gaps for better quality analysis. The statistical significance of the data was tested on an annual and seasonal basis.

Different authors analyzed different streamflow trends on a national, catchment, continental or worldwide basis. Instead of the large media attention worldwide for the studies about climate change in Europe, there is a general perception about increasing the flood features and their magnitude. The losses from floods can cost tens of billions of Euros (Svensson, Kundzewicz, Maurer 2005). A wider Pan-European study shows a decreasing streamflow trend in parts of Eastern and Southern Europe, which also spreads throughout Central Europe and all the changes which are part of a coherent pattern of change (Stahl et al. 2010). The mountain basins were detected like most vulnerable systems, analyzed from the aspect of climate change detection, mainly connected to the fast runoff through the large slope stream profile and snow melt processes (Birsan et al. 2005).

The Southeastern Europe studies in general show decreasing streamflow trends. The article about streamflow trends in Serbia shows a decrease of $30 \%$ of the runoff in the past 100 years analyzed at 8 natural regime streams. (Dimkić, Despotović 2012).

An article in Turkey about stremflow trends in majority shows significant downward trends: 11 stations with downward for maximum flows, 27 downward trends on mean flows, and 40 trends with minimum streamflow for minimum flows, all from a total of 96 gauges. The trends with significant downward are located in the western part of the country (European Turkey and Anatolya).

An article about Romania shows predominantly trends of significant decrease in the summer and trends of significant increase in winter and autumn, done by an analysis on 44 stations (Birsan et al. 2005). The $20 \%$ are decreasing trends and $16 \%$ are increasing. The second artcle about the Romanian seasonal stremflow trends results with the thesis that the winter and spring streamflow has an increasing trend because of the increase of the temperature and faster melting of the snow, the summer decrease is because of the trend of higher temperature and the increase in autumn connected with the trend of rainfall increase

The study of the streamflow trends of the river Struma in the Central Balkans region (Bulgaria, Macedonia and Greece) shows significant downward trends of 
the streamflow besides the numerous gaps in the streamflow time series (Antonopoulos, Papamichail, Mitsiou 2001).

Additionally, the article about the Mediterranean stremflow trends is analyzing three significant catchments: Ebro, Adige in Italy and the river Sava on the Balkan Peninsula. The study about the streamflow trend of the River Sava based on 20 stations covers the terrain of Slovenia, Croatia, Bosnia and Herzegovina and Serbia. The results show trends of decrease in 10 of 20 stations with $50 \%$, without any significant trend of increase (Lutz et al. 2016).

\subsection{Study area}

Macedonia is located in Southeastern Europe, a central part of the Balkan Peninsula and has an area of $25,713 \mathrm{~km}^{2}$. The ground forms are predominantly hillymountainous and the elevation varies from the lowest point of $54 \mathrm{~m}$ a.s.l. (in Gevgelija Basin) to 2,764 m a.s.l. (peak Golem Korab on Korab Mountain), with almost 30 basins and almost the same number of mountain ridges. According to the geographical latitude and ground conditions, it is divided to the larger continental climate region in the north and the smaller moderate Mediterranean climate region to the Southeast and Southwest. The high mountains with its elevation above 2,000 $\mathrm{m}$ a.s.l. with a mountainous climate are distributed in the country parallel with the plains. The country's aquatics belong predominantly to the Aegean Basin with $22,319 \mathrm{~km}^{2}$, and to the Adriatic Basin with $3,350 \mathrm{~km}^{2}$. The main river basin with its tributaries Lepenec, Pchinja, Bregalnica, Treska and the river Crna has a drainage area in Macedonia of $20,535 \mathrm{~km}^{2}$, of which the biggest one is Vardar, with a total length of $388 \mathrm{~km}$ ( $301 \mathrm{~km}$ in Macedonia), which streams directly to the Aegean Sea at the gulf of Termaikos near the city of Solun (Thessaloniki) in Greece. The second basin belongs to the river Strumica with a total length of $114 \mathrm{~km}, 81 \mathrm{~km}$ in Macedonia (right tributary of the river Struma in Bulgaria). The main river in the Adriatic Basin is Crni Drim with two large lakes, Ohrid and Prespa (connected with an underground inflow to lake Ohrid), and the largest tributary of Crni Drim from the north, the river Radika. The selected gauges on the 13 streams are shown on Figure 1 with their basic characteristics in Table 1.

The river regime is nival-pluvial, with its maximum amounts in spring and autumn; in all basins except the Gevgelija-Valandovo basin, which is moderately Mediterranean with one minimal streamflow in the summer and its maximum in the winter, with the primary minimum in the summer and the secondary minimum in the winter (Vasileski, Radevski 2014). In the larger Continental streamflow in the regime area, floods usually happen in autumn, spring and during the summer after intensive rainfalls (Radevski, Gorin 2017). 
Table 1 - Basic characteristics of analyzed natural flow streams

\begin{tabular}{llllcccc}
\hline Basin & $\begin{array}{l}\text { River (R.) } \\
\text { Lake (L.) }\end{array}$ & Tributary & Gauge & $\begin{array}{c}\text { Upstream } \\
\text { drainage }\left(\mathrm{km}^{2}\right)\end{array}$ & $\begin{array}{c}\text { Gauge } \\
\text { Elevation }(\mathrm{m})\end{array}$ & $\begin{array}{c}\text { Mean flow } \\
\left(\mathrm{m}^{3} / \mathrm{s}\right)\end{array}$ & $\begin{array}{l}\text { Time series } \\
\text { period }\end{array}$ \\
\hline Aegean & Crna & Boishka & Boishte & 22.02 & 823.95 & 0.763 & $1961-2000$ \\
Adriatic & Prespa L. & Brajchinska & Brajchino & 61.50 & 975.29 & 0.946 & $1961-2010$ \\
Aegean & Vardar & Crna & Dolenci & 216.50 & 739.00 & 2.540 & $1961-2000$ \\
Aegean & Zletovska & Emirica & Emirica-Vliv & 32.42 & 559.70 & 0.493 & $1961-2000$ \\
Adriatic & Mala R. & Garska & Gari & 25.95 & $1,011.02$ & 1.170 & $1961-2000$ \\
Aegean & Vardar & Kadina & Krusha & 9.46 & $1,305.91$ & 1.380 & $1961-2000$ \\
Aegean & Crna & Konjarska & Skochivir & 64.19 & 576.51 & 0.751 & $1961-2000$ \\
Aegean & Pchinja & Kriva & Zidilovo & 78.6 & 786.00 & 1.250 & $1961-2005$ \\
Adriatic & Koselska R. & Leva & LevaReka & 25.12 & $1,004.51$ & 0.434 & $1961-2000$ \\
Aegean & Strumica & Plavaja & Podaresh & 118.34 & 393.37 & 0.917 & $1961-2004$ \\
Adriatic & Ohrid L. & Sateska & Botun & 362.00 & 743.18 & 5.960 & $1961-2010$ \\
Adriatic & Mala R. & Tresonechka & Tresonche & 71.24 & 601.02 & 1.142 & $1961-2000$ \\
Aegean & Bregalnica & Zletovska & Zletovo & 117.96 & 519.51 & 1.980 & $1961-2000$ \\
\hline
\end{tabular}

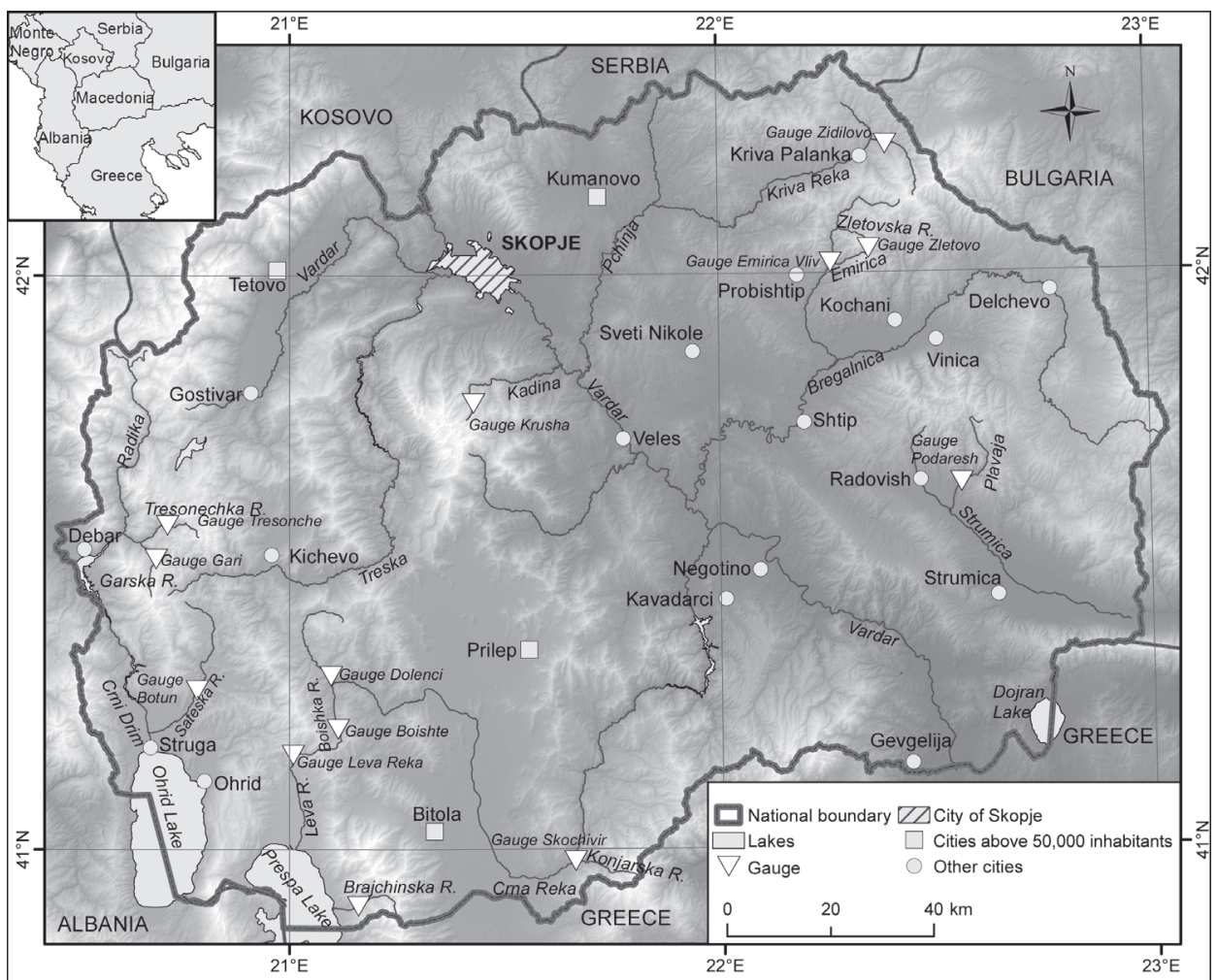

Fig. 1 - Topographical map of Macedonia with streams and gauges 


\subsection{Data}

The streamflow measurement conditions in Macedonia are instrumentally available in general in the second part of the $20^{\text {th }}$ century. There are active stations before this period of time, but those are built on the main streams in the towns where there is a significant human influence in the river regime. According to the aim of the study to work with natural regime streams and the trend detection on river streamflow, we choose the data with at least 40 years of record on 13 mountainous gauges.

The previous scientific studies show different length of the time series, but no less than a period of 20 years in Nepal (Gautam, Acharua 2012), 25 years in Turkey (Cigizoglu, Bayazit, Önöz 2005), 30 years in Austria (Kormann et al. 2015), Canada (Yue, Pilon, Phinney 2003; Zhang et al. 2001), Switzerland (Birsan et al. 2005) and Australia (Zhang et al. 2016), 31 years in Taiwan (Yeh et al. 2015), 34 years in Romania (Birsan et al. 2014), 40 years in Iran (Abhari, Tabari, Talaee 2013) and Spain and Potugal (Lorenzo-Lacruzet al. 2012; Martínez-Fernández, Sánchez, Herrero-Jiménez 2013), 50 years in China (Zhang et al. 2008), Alaska (Bennett, Cannon, Hinzman 2015) and Slovakia (Blahušiaková, Matoušková 2015), 52 years in Germany (Petrow, Merz 2009), 70 years in the UK (Hannaford, Buys 2012), 80 years in the USA (Lins, Slack 1999) and 100 years in Serbia (Dimkić, Despotović 2012). The time series were used for trend analysis of annual and seasonal streamflow trends (Table 2). The streamflow trend results represent a significant base for future analysis of the climate change, analyzed separately or along with the precipitation trend studies (Pakalidou, Karacosta 2016), especially in natural or near natural catchments (Novotny, Stefan 2007; Jiang, Zhou, Cheng 2007).

Table 2 - Streamflow variables abbreviations for specific period

\begin{tabular}{lll}
\hline Streamflow variable & Abbreviation & Period \\
\hline Annual maximum daily flow & AMAXF & \\
Annual mean daily flow & AMEANF & Hydro. Year (X-IX) \\
Annual minimum daily flow & AMINF & \\
Winter maximum, mean and min daily flow & WMAXF, WMEANF, WMINF & Winter (XII-II) \\
Spring maximum, mean and minimum daily flow & SPMAXF, SPMEANF, SPMINF & Spring (III-V) \\
Summer maximum, mean and minimum daily flow & SUMAXF, SUMEANF, SUMINF & Summer (VI-VIII) \\
Autumn maximum, mean and minimum daily flow & AUMAXF, AUMEANF, AUMINF & Autumn (IX-XI) \\
\hline
\end{tabular}




\section{Methodology}

To obtain relevant results it is necessary to choose a river with natural or near natural regime without significant human activities, canals, dams, ameliorative or water supply systems on the stream, and there are also waste water treatment plants that affect water regime in time, land degradations, deforestations, infrastructures etc.

According to the previous studies where the streamflow trend was analyzed, the main methodological approach is the non parametric Mann-Kendall (MK) trend test (Mann 1945, Kendall 1975). The work methodology was connected firstly with the trend-free pre-whitening procedure (TFPW) for removal of serial correlation in the time series, described in details by Yue et al. (2002) and Yue et al. (2003), and also a presentation of the result quality of the studies with and without using the pre-whitening method. This methodology was chosen especially for inclined streamflow time series and it requires minimum assumptions to be made by data (Kundzewicz, Robson 2004). Also, the trend analysis with small differences in scientific approach was widely used in different countries and regions by many authors: Abhari, Tabari, Talaee (2013); Bennett, Cannon, Hinzman (2015); Birsan et al. (2005); Birsan et al. (2012); Birsan et al. (2014); Blahušiaková, Matoušková (2015); Cigizoglu, Bayazit, Önöz (2005); Dimkić, Despotović (2012); Gautam, Acharua (2012); Hannaford, Buys (2012); Kormann et al. (2015); Kundzewicz et al. (2005); Lins, Slack (1999); Martínez-Fernández, Sánchez, Herrero-Jiménez (2013); Masih et al. (2011); Petrone et al. (2010); Petrow, Merz (2009); Yeh et al. (2015); Yue, Pilon, Phinney (2003); Zhang et al. (2001); Zhang et al. (2008); Zhang et al. (2016).

For the basic analysis of trend testing, the significance level (a) of 0.1 was used, and for the trend power/magnitude additionally $\mathrm{a}=0.05$ and $\mathrm{a}=0.01$ were used in the XLSTAT software. This software allows a complete MK-TRPW procedure, successfully implemented in significant previous studies (Zhang et al. 2008, Gavrilov et al. 2015). Increasing and decreasing trends were detected according to the sign +/- in statistics $S$. After obtaining the results, they were thematically mapped in three annual (AMAXF, AMEANF, AMINF) and 12 seasonal maps (WMAXF, WMEANF, WMINF, SPMAXF, SPMEANF, SPMINF, SUMAXF, SUMEANF, SUMINF, AUMAXF, AUMEANF and AUMINF). In MK testing there are two hypotheses: $\mathrm{H}_{0}$ There is no significant trend in the time series and $\mathrm{H}_{\mathrm{a}}$ - there is a significant trend in the time series. The statistic operations test requires the computation of MK $S$ statistics, which is determined as followed:

$$
S=\sum_{i=1}^{n-1} \sum_{j=i+1}^{n} \operatorname{sgn}\left(T_{j}-T_{i}\right)
$$


Where

$$
\operatorname{sgn}\left(T_{j}-T_{i}\right)=\left\{\begin{array}{r}
1 \text { if } T_{j}-T_{i}>0 \\
0 \text { if } T_{j}-T_{i}=0 \\
-1 \text { if } T_{j}-T_{i}<0
\end{array}\right.
$$

In the formula $T_{j}$ and $T_{i}$ are the time series of annual/seasonal values of streamflow in years $j=i+1, i+2, i+3$, and $i=1,2,3, \ldots, n-1$, where $j>i$, and $n$ is the last year of the time series. According to the equations, if the streamflow is increasing in the following year, the $S$ is increased by 1 , and in opposite, if the streamflow is decreasing in the following year, the statistic $S$ is decreased by 1 . Apositive value of $S$ indicates an increasing trend and a negative value indicates a decreasing trend in streamflow time series.

$$
Z=\left\{\begin{array}{cc}
\frac{S-1}{\sigma} & \text { for } S>0 \\
0 & \text { for } S=0 \\
\frac{S+1}{\sigma} & \text { for } S<0
\end{array}\right.
$$

Where $Z$ represents the value of the normalized/standard test statistics, $\sigma^{2}$ is the variance of the near normally distributed statistics $S$ for $n \geq 10$. For measuring the significance of the streamflow trend, the $\mathrm{p}$-value was computed (significance level $a=0.1,0.05,0.01)$. If the value of $p$ is lower than 0.01 , it means that the streamflow trend is very strong, if $0.049>p>0.01$ the trend is strong, if $0.1>p>0.05$ the trend is moderate $\left(\mathrm{H}_{\mathrm{a}}\right.$ accepted) and if $p>0.1$, there is no significant trend of streamflow time series, which means that the $\mathrm{H}_{0}$ is accepted.

$$
p=[1-f(Z)]
$$

The slope $\beta$ is estimated with the thenonparametric Theil-Sen method which is suitable for a nearly linear trend in the variable $x$ and is less affected by a nonnormal data and outliers, made by Sen (1968) and Hirsch, Slack, Smith (1982). The slope is computed between all pairs $i$ of the variable $x$ :

$$
\beta_{i}=\frac{x_{j}-x_{k}}{j-k}
$$

where $j>k ; j=2, \ldots n ; k=1, \ldots, n-1$ and $i=1 \ldots$ N. For $n$-values in the streamflow series $x$, will result in $N=n(n-1) / 2$ values of $\beta$ (which is the median over the all combinations of record pairs for the dataset). The Sens slope is presented in $\mathrm{m}^{3} / \mathrm{s}$ per year, with sign + for the increasing and - for the decreasing trend.

Additionally, to detect the cause of the streamflow trend, the mean annual temperature $\left({ }^{\circ} \mathrm{C}\right)$ and the precipitation sums $(\mathrm{mm})$ with the record period between 1971-2010 were analyzed with the same methodology as the streamflow (Gavrilov et al. 2015; Pakalidou, Karacosta 2016). 


\section{Results}

The results gathered from the Mann-Kendall test for annual minimum, mean and maximum streamflow are shown in Table 3 . According to the calculated statistic $S$, only downward trends were detected in the whole analysis, and no significant increasing trends in the trend analysis for the 13 gauges. The value of $S$ for AMAXF, AMINF and AMEAN varies from +163 at the Brajchino gauge, to -513 at the gauge of Zidilovo. In the seasonal analysis, the $S$ statistics varies from +287 in the spring at the gauge of Brajchino to -461 in summer at the gauge of Zidilovo. There are significant downward trends of AMAXF on the stations Dolenci, EmiricaVliv, Zidilovo and Zletovo. In AMEANF there are 4 significant decreasing trends in the stations Emirica-Vliv, Zidilovo, Podaresh and Zletovo and in AMINF there are 5 significant decreasing trends in the stations of Boishte, Dolenci, Emirica, Krusha and Zletovo.

The results of the Mann-Kendall test for WMAXF, WMEANF and WMINF are shown in Table 4. The results of Mann-Kendall test for seasonal minimum, mean and maximum streamflow are shown in Table 3. According to the calculated statistic $S$, downward trends were detected in the whole analysis, there are no significant increasing trends and stations without any trends. There are significant downward trends of WMAXF only on the station of Zidilovo. In WMEANF, there are 4 significant decreasing trends in the stations of Emirica-Vliv, Skochivir, Zidilovo and Zletovo, and in WMINF there is only one significant decreasing trend in the station of Skochivir.

According to the calculated statistic $S$, for SPMAXF, SPMEANF and SPMINF, downward trends were detected in whole analysis, there are no significant

Table 3 - Annual results according to the MK test $(a=0.1)$

\begin{tabular}{|c|c|c|c|c|c|c|c|c|}
\hline N & River & Gauge & $\operatorname{Max}(P)$ & $\operatorname{Max}(\mathrm{S})$ & Mean (p) & Mean (S) & $\operatorname{Min}(p)$ & $\operatorname{Min}(S)$ \\
\hline 1 & Boishka & Boishte & 0.332 & -123 & 0.178 & -174 & 0.008 & -332 \\
\hline 2 & Brajchinska & Brajchino & 0.385 & 163 & 0.570 & -103 & 0.804 & 45 \\
\hline 3 & Crna & Dolenci & 0.047 & -252 & 0.115 & -203 & 0.012 & -318 \\
\hline 4 & Emirica & Emirica-Vliv & 0.087 & -221 & 0.026 & -280 & 0.019 & -333 \\
\hline 5 & Garska & Gari & 0.531 & -80 & 0.330 & -129 & 0.226 & -158 \\
\hline 6 & Kadina & Krusha & 0.853 & -25 & 0.107 & -206 & 0.040 & -257 \\
\hline 7 & Konjarska & Skochivir & 0.821 & 33 & 0.118 & -196 & 0.587 & -71 \\
\hline 8 & Kriva & Zidilovo & 0.008 & -513 & 0.017 & -300 & 0.380 & -112 \\
\hline 9 & Leva & Leva Reka & 0.383 & -112 & 0.249 & -148 & 1.000 & 1 \\
\hline 10 & Plavaja & Podaresh & 0.270 & -165 & 0.035 & -308 & 0.103 & -241 \\
\hline 11 & Sateska & Botun & 0.220 & -222 & 0.510 & -121 & 0.703 & 68 \\
\hline 12 & Tresonechka & Tresonche & 0.723 & -46 & 0.339 & -127 & 0.239 & -154 \\
\hline 13 & Zletovska & Zletovo & 0.076 & -229 & 0.039 & -262 & 0.034 & -304 \\
\hline
\end{tabular}


Table 4 - Seasonal results of $\mathrm{p}$-value according to the MK test $(a=0.1)$

\begin{tabular}{|c|c|c|c|c|c|c|c|c|c|c|c|c|}
\hline \multirow[t]{2}{*}{ Gauge } & \multicolumn{3}{|c|}{ Winter (p) } & \multicolumn{3}{|c|}{ Spring (p) } & \multicolumn{3}{|c|}{ Summer (p) } & \multicolumn{3}{|c|}{ Autumn (p) } \\
\hline & Max & Mean & Min & Max & Mean & Min & Max & Mean & Min & Max & Mean & Min \\
\hline Boishte & 0.260 & 0.352 & 0.123 & 0.540 & 0.388 & 0.384 & 0.541 & 0.181 & 0.021 & 0.753 & 0.274 & 0.017 \\
\hline Brajchino & 0.468 & 0.202 & 0.169 & 0.143 & 0.864 & 0.120 & 0.283 & 0.251 & 0.732 & 0.694 & 0.276 & 0.556 \\
\hline Dolenci & 0.241 & 0.256 & 0.145 & 0.222 & 0.350 & 0.380 & 0.176 & 0.118 & 0.040 & 0.880 & 0.135 & 0.010 \\
\hline Emirica & 0.250 & 0.014 & 0.265 & 0.469 & 0.185 & 0.201 & 0.208 & 0.055 & 0.266 & 0.289 & 0.135 & 0.127 \\
\hline Gari & 0.673 & 0.342 & 0.358 & 0.847 & 0.566 & 0.720 & 0.339 & 0.300 & 0.248 & 0.503 & 0.228 & 0.148 \\
\hline Krusha & 0.981 & 0.263 & 0.289 & 0.857 & 0.777 & 0.948 & 0.209 & 0.033 & 0.278 & 0.919 & 0.226 & 0.310 \\
\hline Skochivir & 0.795 & 0.038 & 0.037 & 0.157 & 0.943 & 0.032 & 0.225 & 0.160 & 0.577 & 0.596 & 0.070 & 0.114 \\
\hline Zidilovo & 0.048 & 0.032 & 0.233 & 0.017 & 0.115 & 0.674 & 0.012 & 0.072 & 0.629 & 0.032 & 0.090 & 0.824 \\
\hline Leva Reka & 0.413 & 0.325 & 0.634 & 0.852 & 0.368 & 0.387 & 0.189 & 0.257 & 0.956 & 0.242 & 0.236 & 0.944 \\
\hline Podaresh & 0.946 & 0.276 & 0.973 & 0.031 & 0.057 & 0.270 & 0.476 & 0.021 & 0.105 & 0.347 & 0.307 & 0.092 \\
\hline Botun & 0.382 & 0.486 & 0.890 & 0.664 & 0.467 & 0.564 & 0.126 & 0.463 & 0.649 & 0.355 & 0.414 & 0.964 \\
\hline Tresonche & 0.696 & 0.321 & 0.429 & 0.884 & 0.577 & 0.803 & 0.347 & 0.310 & 0.214 & 0.472 & 0.256 & 0.149 \\
\hline Zletovo & 0.315 & 0.031 & 0.264 & 0.298 & 0.234 & 0.266 & 0.136 & 0.051 & 0.221 & 0.188 & 0.171 & 0.248 \\
\hline
\end{tabular}

increasing trends and stations without any trends. There are significant downward trends of SPMAXF on the stations of Podaresh and Zidilovo. In SPMEANF, there is only one significant decreasing trend on the station of Podaresh, and in SPMINF there is a significant decreasing trend on station of Skochivir.

The results of the Mann-Kendall testfor SUMAXF, SUMEANF and SUMINF are shown in Table 4. According to the calculated statistic $S$, downward trends were detected in the whole analysis, there are no significant increasing trends and stations without trends. There is a significant downward trend of SUMAXF on the station of Zidilovo. In SUMEANF there are 5 significant decreasing trends on the stations of Emirica-Vliv, Krusha, Zidilovo, Podaresh and Zletovo, and in SUMINF there is a significant decreasing trend in the station of Dolenci.

The autumn results of the statistic $S$ are showing downward streamflow trends, there are no significant increasing trends and stations without trends. There are significant downward trends of AUMAXF on the station of Zidilovo. In AUMEANF there are two significant decreasing trends on the stations of Skochivir and Zidilovo, and in AUMINF there are 3 significant decreasing trends in the stations of Boishte, Dolenci and Podaresh.

As shown in Table 4, the majority of the data results are insignificant, generally downward trends, which means, in the seasonal results there is a distinction between the stations with significant trends (Skopchivir, Zidilovo, Podaresh and Emirica) and the stations of Brajchino, Gari, Botun and Tresonche, all located on the west, where there is not one significant downward trend.

As shown in Table 5, the value of the statistic $S$ and almost all values is negative, which means that the trend is in the majority of the downward data results, but 
Table 5 - Seasonal results of statistic S according to the MK test

\begin{tabular}{|c|c|c|c|c|c|c|c|c|c|c|c|c|}
\hline \multirow[t]{2}{*}{ Gauge } & \multicolumn{3}{|c|}{ Winter (S) } & \multicolumn{3}{|c|}{ Spring (S) } & \multicolumn{3}{|c|}{ Summer (S) } & \multicolumn{3}{|c|}{ Autumn (S) } \\
\hline & Max & Mean & Min & Max & Mean & Min & Max & Mean & Min & Max & Mean & Min \\
\hline Boishte & -146 & -122 & -195 & -78 & -110 & -109 & -80 & -170 & -292 & 40 & -140 & -300 \\
\hline Brajchino & 134 & -237 & -256 & 287 & 31 & -287 & -206 & -205 & -61 & 76 & -200 & -107 \\
\hline Dolenci & -152 & -146 & -180 & -154 & -118 & -110 & -178 & -199 & -257 & -20 & -198 & -327 \\
\hline Emirica-Vliv & -149 & -314 & -142 & -90 & -166 & -164 & -171 & -238 & -145 & -137 & -190 & -198 \\
\hline Gari & -53 & -121 & -119 & -26 & -77 & -48 & -119 & -133 & -149 & -88 & -157 & -188 \\
\hline Krusha & 4 & -142 & -137 & 24 & -36 & -9 & -162 & -268 & -136 & -14 & -166 & -135 \\
\hline Skochivir & -34 & -270 & -264 & 183 & -10 & -265 & -166 & -176 & -71 & -74 & -238 & -197 \\
\hline Zidilovo & -347 & -278 & -153 & -413 & -196 & -54 & -461 & -222 & -61 & -387 & -216 & -29 \\
\hline Leva Reka & -103 & -130 & -62 & -25 & -114 & -109 & -172 & -144 & 8 & -151 & -149 & -10 \\
\hline Podaresh & -11 & -164 & 6 & -345 & -276 & -167 & -105 & -342 & -249 & 143 & -150 & -248 \\
\hline Botun & -153 & -129 & -26 & -76 & -129 & -102 & -281 & -133 & 81 & -173 & -146 & -9 \\
\hline Tresonche & -49 & -127 & -102 & -20 & -75 & -34 & -117 & -131 & -160 & -94 & -149 & -188 \\
\hline Zletovo & -131 & -278 & -142 & -129 & -150 & -144 & -203 & -242 & -162 & -169 & -174 & -150 \\
\hline
\end{tabular}

Table 6 - Number of statistically significant decreasing trend gauges $(n / 13)$ according to the MK test results

\begin{tabular}{llllrrrrrrr}
\hline Time & A & $\%$ & W & $\%$ & Sp & $\%$ & Su & $\%$ & Au & $\%$ \\
\hline Max & 4 & 31 & 1 & 8 & 2 & 15 & 1 & 8 & 1 & 8 \\
Mean & 4 & 31 & 4 & 31 & 1 & 8 & 5 & 39 & 2 & 15 \\
Min & 5 & 39 & 1 & 8 & 1 & 8 & 1 & 8 & 5 & 39 \\
\hline
\end{tabular}

predominantly insignificant. A very small number of cases is upward but all are insignificant. Significant downward trends are detected in all seasons.

Besides the small number of analyzed stations, there is also a tabular in percentage too, and also graph presentations of the significant downward streamflow trend results. In the annual results for AMAXF, AMEANF and AMINF, more than $30 \%$ of the gauges show to be significant. The process of water losses in streams is less evident in spring, $8 \%$ for SPMEANF and SPMINF. In the summer, the downward trend of $39 \%$ was detected for SUMEANF, but in autumn, the same percentage is for AUMINF. In this analysis there is no streamflow variable besides the season without any downward trend. The power is predominantly strong, especially for the annual stremflow time series and the winter season. The moderate downward trend power was detected in the summer (Table 6, Fig. 2).

In the thematic mapping of the significant trends in Macedonia, we can clearly come to a conclusion that there are two wider areas with significant trends. The first one is in the North-Eastern part of the country, with significant downward trends in most of the 15 maps for annual and seasonal trends. In this region there 


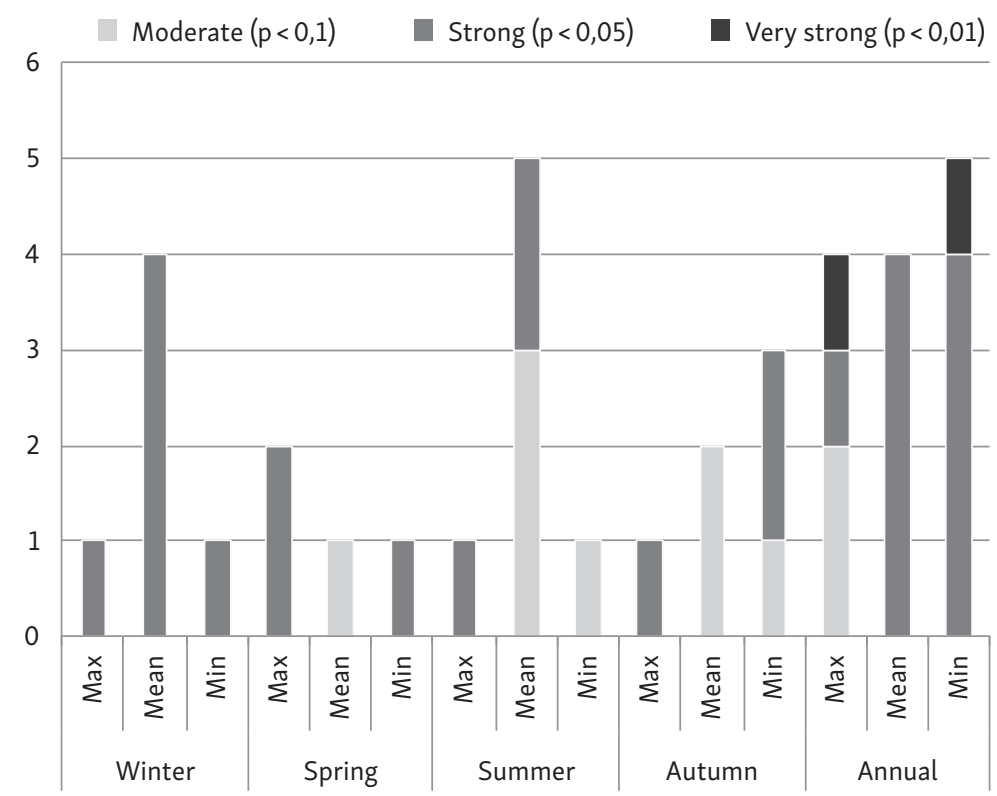

Fig. 2 - Number of gauges with significant decreasing MK test $p$-value with trend magnitude (power)

are two very strong trends with $p<0.01$ for AMAXF in Zidilovo and AMINF in gauge Boishte. It is a region with a continental river regime in the basins of the rivers Bregalnica and Pcinja, part of the Aegean Basin through the river Vardar. The second region with frequently significant trends is in the Western part of the country in the spring area of the river Crna, where there is also one significant and very strong decreasing trend at the gauge of Boishte for AMINF. From all the analyzed data (AMAXF, AMEANF, AMINF, WMAXF, WMEANF, WMINF, SPMAXF, SPMEANF, SPMINF, SUMAXF, SUMEANF, SUMINF, AUMAXF, AUMEANF and AUMINF, a significant downward trend was found in 24 cases in the Eastern part of the Republic of Macedonia, while 12 downward streamflow trends in the Western part of the country (Fig. 3, 4).

The annual and seasonal trends are significantly decreasing in $18.5 \%$ of the cases and in $81.5 \%$ there is no significant downward trend. Not a single case was provided with a significant increasing trend from all 13 selected natural gauges, using the MK test and Sen's slope. The Sen's slope shows $99 \%$ of negative slope values in the range of $0 \mathrm{~m}^{3} / \mathrm{s}$ at several stations, to $1.062 \mathrm{~m}^{3} / \mathrm{s}$ on the gauge of Zidilovo, which is an enormous amount for such a small catchment $\left(78.6 \mathrm{~km}^{2}\right)$. These results show 5 stations with significant decreasing trends in AMINF in the range of $-0.001 \mathrm{~m}^{3} / \mathrm{s}-0.009 \mathrm{~m}^{3} / \mathrm{s}$. The largest values of river discharge are shown in AMAXF for the stations of Zidilovo and Dolenci $\left(-0.336 \mathrm{~m}^{3} / \mathrm{s}\right.$ for AMAXF). The SUMAXF on gauge of Zidilovo is $-0.522 \mathrm{~m}^{3} / \mathrm{s}$ and $-0.275 \mathrm{~m}^{3} / \mathrm{s}$ (Table 7). 
a)

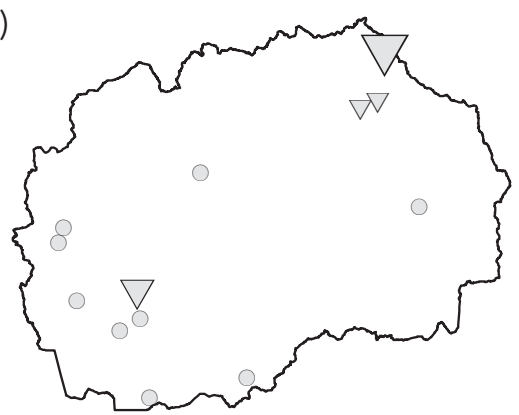

c)

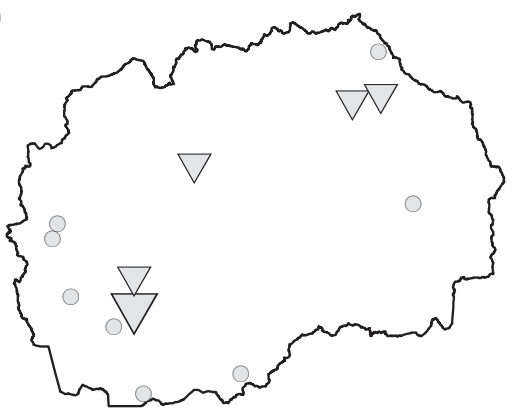

e)

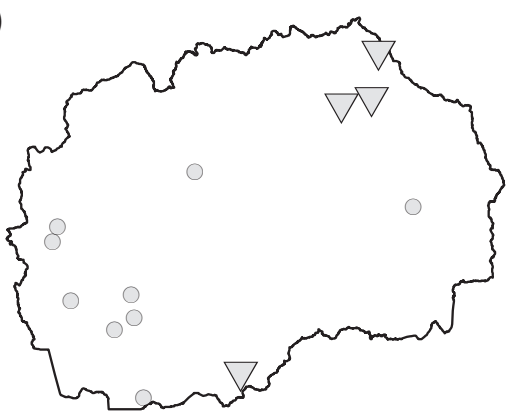

g)

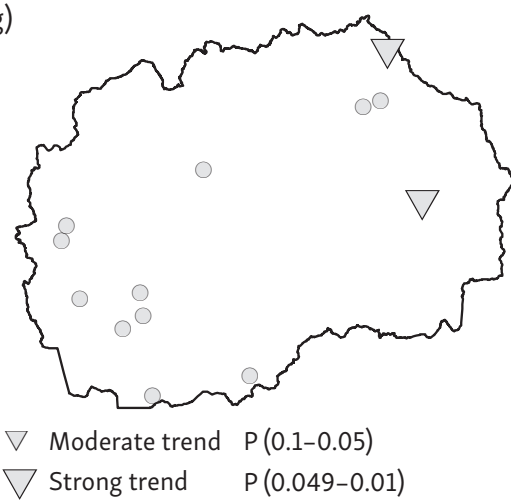

b)

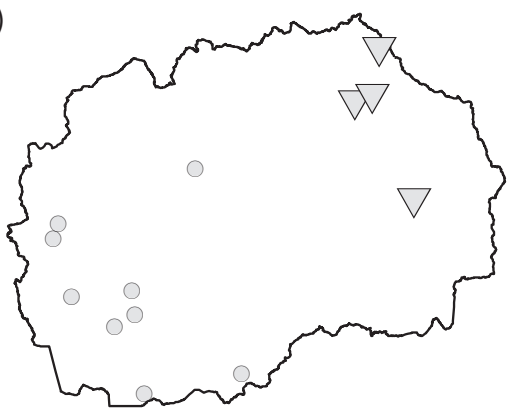

d)

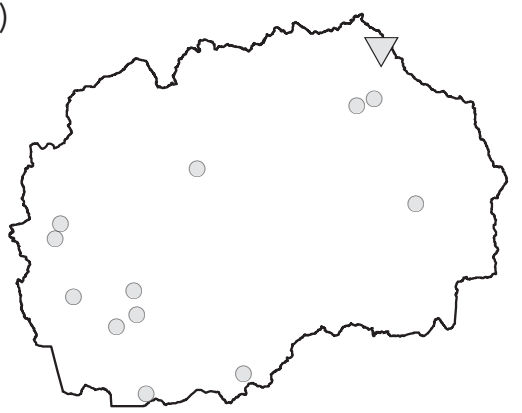

f)

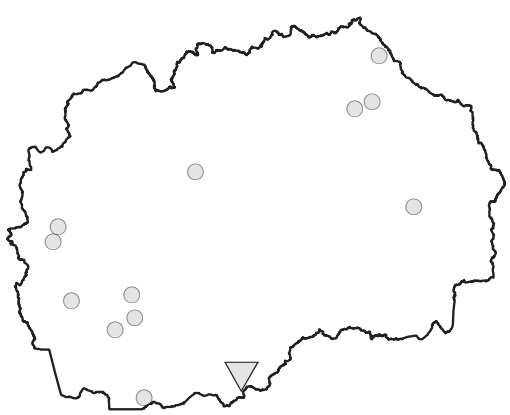

h)

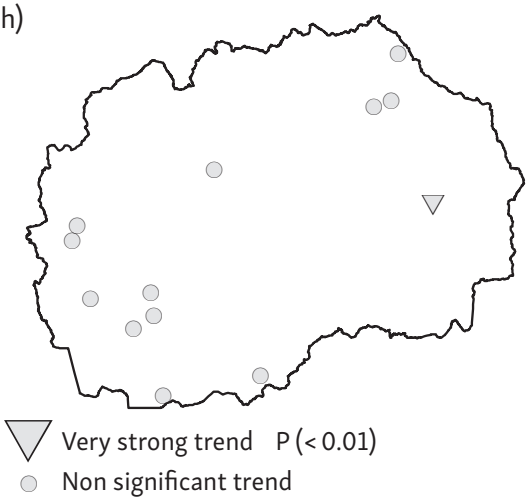

Fig. 3 - Stremflow gauges with significant downward stremflow trend in Macedonia (a) AMAXF, (b) AMEANF, (c) AMINF, (d) WMAXF, (e) WMEANF, (f) WMINF, (g) SPMAXF, (h) SPMEANF) 
i)

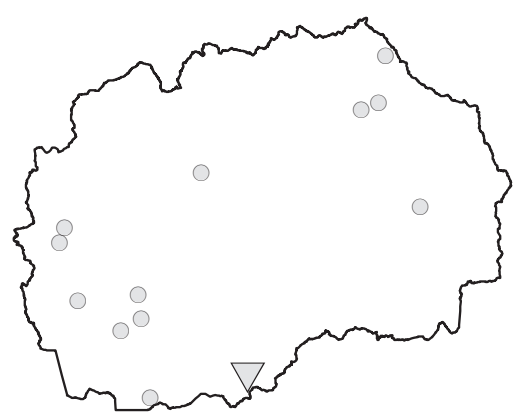

k)

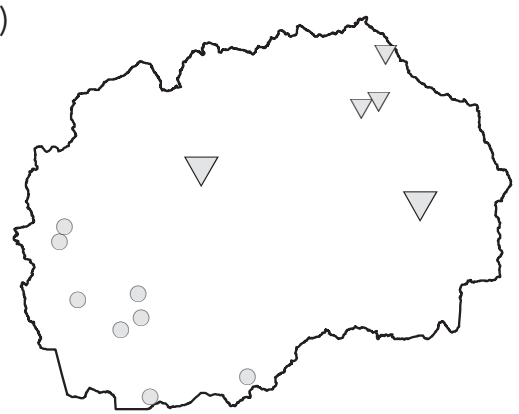

m)

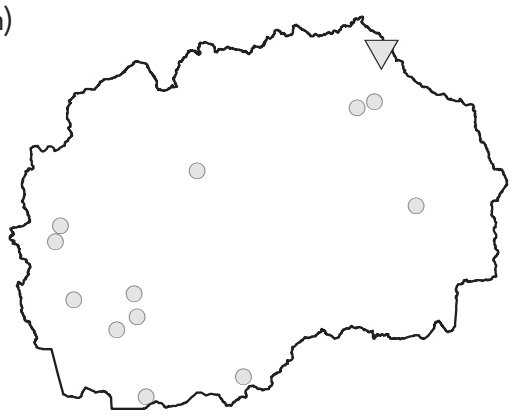

o)

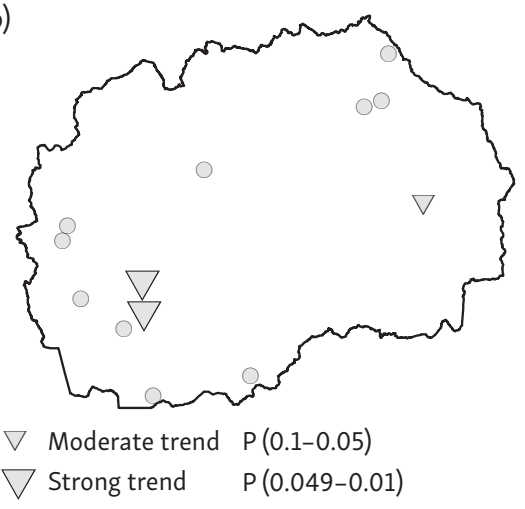

j)

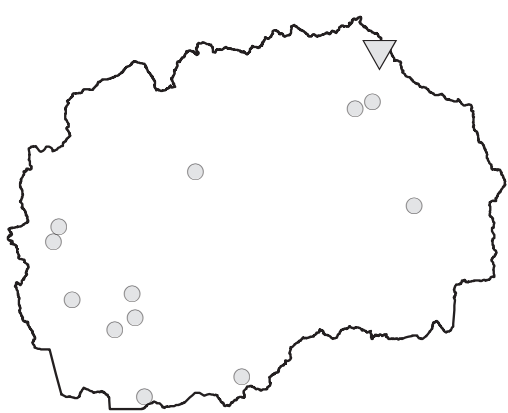

l)

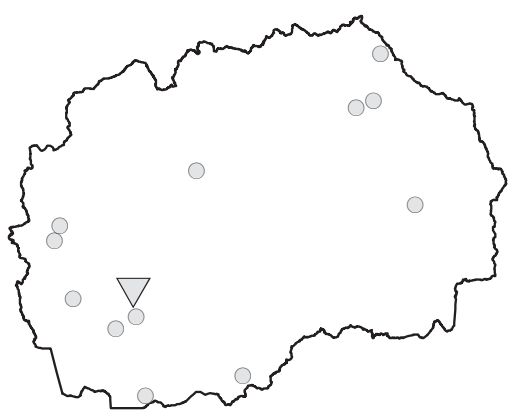

n)

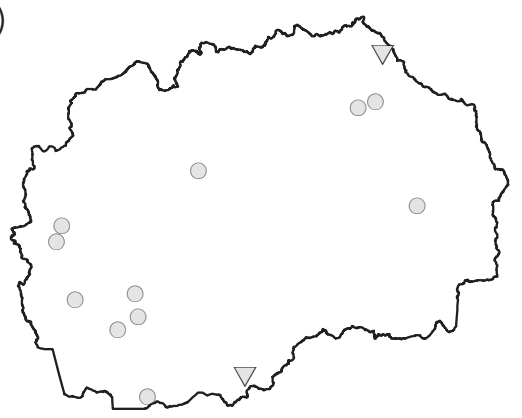

$\nabla$ Very strong trend $P(<0.01)$
Non significant trend

Fig. 4 - Stremflow gauges with significant downward stremflow trend in Macedonia (i) SPMINF, (j) SUMAXF, (k) SUMEANF, (l) SUMIN, (m) AUMAXF, (n) AUMEANF, (o) AUMINF 


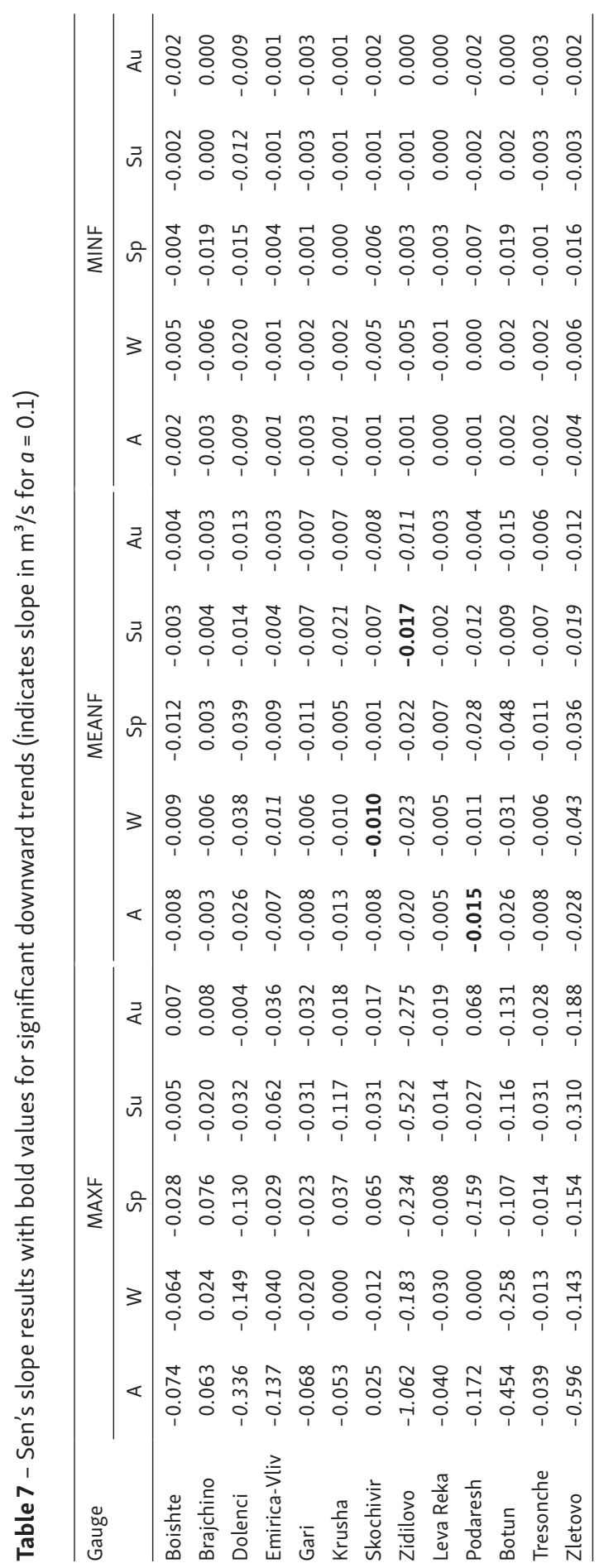


Table 8 - Mann-Kendall and Sen's test trend analysis of annual temperature and precipitation (1971-2010) at 6 meteorological stations in Macedonia

\begin{tabular}{|c|c|c|c|c|c|c|c|c|c|c|}
\hline \multicolumn{2}{|c|}{ Temperature } & \multicolumn{2}{|c|}{ Mann-Kendall } & \multirow[t]{2}{*}{ Sen's } & \multirow[t]{2}{*}{ Trend } & \multirow{2}{*}{$\frac{\text { Precipitation }}{\text { Gauge }}$} & \multicolumn{2}{|c|}{ Mann-Kendall } & \multirow[t]{2}{*}{ Sen's } & \multirow[t]{2}{*}{ Trenc } \\
\hline $\mathrm{N}$ & Gauge & $P$ & S & & & & $P$ & S & & \\
\hline 1 & Berovo & 0.0016 & 402 & 0.0361 & $\uparrow$ & Berovo & 0.8877 & 20.0000 & 0.4185 & 0 \\
\hline 2 & Kochani & 0.0121 & 342 & 0.0420 & $\uparrow$ & Kochani & 0.5493 & -78.0000 & -1.2131 & 0 \\
\hline 3 & Delchevo & 0.9759 & -5 & -0.0007 & 0 & Delchevo & 0.6426 & 60.0000 & 1.3984 & 0 \\
\hline 4 & Bitola & 0.0013 & 410 & 0.0428 & $\uparrow$ & Bitola & 0.9937 & 2.0000 & 0.0129 & 0 \\
\hline 5 & Ohrid & 0.0063 & 338 & 0.0283 & $\uparrow$ & Ohrid & 0.7335 & 53.0000 & 1.4107 & 0 \\
\hline 6 & Shtip & 0.0049 & 355 & 0.0358 & $\uparrow$ & Shtip & 0.7335 & -46.0000 & -1.0057 & 0 \\
\hline
\end{tabular}

Table 8 presents the results of annual mean temperatures and precipitation sums trend analysis with the same methodology as the hydrological with two main meteorological elements in the country. The results from 6 gauges clearly indicate that the streamflow decrease is not a result of the significant precipitation decrease but is a result of the significant average annual temperature increasing, which results with higher percent of evapo-transpiration processes in the country and water loses in the streams. It means that the temperature increasing is a main natural factor for the streamflow downward on several analyzed gauges in this paper. The results show significant upward mean annual temperature at $5 / 6$ gauges.

\section{Discussion}

The results obtained show that in the analyzed 40-50 years period, the natural streamflow trends in Macedonia show frequent significant or insignificant downward trends. There are very rare insignificant cases of increasing streamflow trends, shown in Figures 5, 6 and 7 for annual and seasonal stremflows in Macedonia. The study is complementary with articles mentioned above in the Introduction paragraph, published in relation with the investigated streams in Slovenia, Croatia, Serbia, Bosnia and Herzegovina Greece, Bulgaria, Romania andTurkey. The study of the Mediterranean (Stahl et al. 2010) also shows a decreasing trend in streams with near natural regime, especially in Southern Europe.

Temporally, the AMAXF, AMEANF and AMINF has a stronger downward power than the seasonal trends in winter, spring, summer and autumn, so the annual results should be distinguished from the seasonal. The AMAXF and AMEANF are predominantly downward in the Eastern part of the country which is also more arid, but the AMINF shows 5 downward significant trends randomly distributed through the country. In WMAXF, WMEANF and WMINF there are also strong significantly downward trends in the Eastern part of Macedonia and not any 
significant trend on the West. It is result of the drier winter season with less precipitation. The spring season doesn't have many frequent downward trends with two significant downward stations from total number of 13 stations. In the spring there isn't only water from the precipitation, but also intensive water from the melting of the snows especially in the Western parts of the country. The spring results show only 4 total significant decreasing trends for SPMAXF, SPMEANF and SPMINF, which has a weaker influence to the water management (water replenishment should be quite unaffected). In this case there is not a notable deficit of spring streamflow, which can lead to longer dry season in the summer. The SUMAXF, SUMEANF and SUMINF shows $38 \%$ of decreasing trend gauges on SIMEANF randomly distributed across the state. The AUMAXF and AUMEANF have rare significant downward trends in the Eastern part, while the AUMINF has 3 significant trends in the Western part. The most trend affected season is the summer with $30 \%$ of all detected downward trends, while the least trend affected season is spring with $15 \%$ of all significant downward trends. Strong and a very strong downward trend was found only in $12 \%$ of the cases.

The natural character of the streams indicates the unfavorable situation in the summer due to the extremely high temperatures during dry season. Additionally, the decreasing of the streamflow will raise the stream water pollution and will produce negative effect on the flora and fauna species. In the analysis it should be emphasized that there are two very strong decreasing trends on gauge of Zidolovo for AMAXF and on the gauge of Dolenci for AMINF. Both streams are upstream gauges and are typically mountainous with important role of snowmelt component in their hydrological regime. From a regional point of view, the most affected part of the country is the Eastern which is more arid, with lower mountains and is located far from wet Western masses coming from the Mediterranean.

Compared with the other studies from the region, it is evident that there is a range from $20 \%$ of significant downward trends in Greece on the river Struma (Antonopoulos, Papamichail, Mitsiou 2001), and up to 50\% of significant downward trends on the Sava River gauges (Lutz et al. 2016). In the case of Macedonia for annual streamflow, in most of the cases we have $34 \%$ of significantly downward trends, while in the seasonal trend analysis it shows a lower percentage of $16 \%$. The streamflow trends in Macedonia could be a part of a wider continental pattern of European streamflows with a global streamflow increasing in Northern Europe and a trend of streamflow decreasing in Southern Europe (Stahl et al. 2010).

The recent hydrological trends in Macedonia indicate a necessity for improving the water management from State authorities, reestablishing of the gauging network in the country from both climatological and hydrological data. Besides the natural climate change which drives the streams through precipitation and temperature, there are several human drives such as agriculture water irrigation, pollution, water supply of the settlements and industry. 
Besides the missing anthropogenic factors in the analysis, the main cause of the streamflow decreasing trend is the air temperature rising in the country. From the 6 analyzed gauges, 5 show upward significant trends according to the MannKendall and Sen's test. There is no significant decreasing of the precipitation.

\section{Conclusions}

The study has provided a comprehensive analysis of trends in minimum, mean and maximum streamflow in the Republic of Macedonia. The results from this paper are complementary with South-Eastern and Mediterranean studies, who also indicate a generally decreasing trend in the streamflow. The streamflow loses are occurred in all seasons, but especially for AMINF and SUMEANF. The streamflow in winter is decreasing in the Eastern part of the country, while in the West, it is without any significant trend. In opposite, a number of decreasing trends in the West is detected in summer and autumn. In spring there isn't any spatial concentration of decreasing trends.

The cause for streamflow decreasing is not the precipitation, nor its significant decreasing, but the significant upward trend of the mean annual temperature according to the results from the rising of the evapo-transpiration rate and drying the catchment water.

The study indicates the climate change itself caused by natural regimes stremflow trends, all of the gauges are selected in the headwaters to exclude any significant human influence and compared with numerous studies where authors have analyzed all gauges besides the regime changes made by humanity. This was quite easy in the predominantly hilly-mountainous country with stream headwaters located above 1,500 $\mathrm{m}$ a.s.l., where there is a low population density and no hydrotechnical buildings, river regulations, land irrigation and systems. The obtained results could be additionally extrapolated to the wider European study along with other Balkan states aiming for better understanding of the streamflow trends.

A deeper analysis compared with the precipitation data will be useful for climate change studies, water management plans and building new dams to keep the water for the drier summer season. The main contribution of the present article is a rare collection of natural catchment regime results about the streamflow trends in the country with a problem of measuring and failing to measure a river water stage because of lack of funds. 


\section{References}

ABGHARI, H., TABARI, H., TALAEE, P.H. (2013): River flow trends in the west of Iran during the past 40 years: Impact of precipitation variability. Global and planetary change, 101, 52-60. DOI: $10.1016 /$ j.gloplacha.2012.12.003.

ANTONOPOULOS, V.Z., PAPAMICHAIL, D.M., MITSIOU, K.A. (2001): Statistical and trend analysis of water quality and quantity data for the Strymon River in Greece, Hydrol. Earth Syst. Sci., 5, 679-692. DOI:10.5194/hess-5-679-2001.

BENNETT, K.E., CANNON, A.J., HINZMAN, L. (2015): Historical trends and extremes in boreal Alaska river basins. Journal of Hydrology, 527, 590-607. DOI: 10.1016/j.jhydrol.2015.04.065.

BIRSAN, M.V., MOLNAR, P., BURLANDO, P., PFAUNDLER, M. (2005): Streamflow trends in Switzerland. Journal of Hydrology, 314, 1, 312-329. DOI: 10.1016/j.jhydrol.2005.06.008.

BIRSAN, M.V., ZAHARIA, L., CHENDES, V., BRANESCU, E. (2012): Recent trends in streamflow in Romania (1976-2005). Rom Rep Phys, 64, 1, 275-280.

BIRSAN, M.V., ZAHARIA, L., CHENDES, V., BRANESCU, E. (2014): Seasonal trends in Romanian streamflow. Hydrological Processes, 28, 15, 4496-4505. DOI: 10.1002/hyp.9961.

BLAHUŠIAKOVÁ, A., MATOUŠKOVÁ, M. (2015): Rainfall and runoff regime trends in mountain catchments (Case study area: the upper Hron River basin, Slovakia). Journal of Hydrology and Hydromechanics, 63, 3, 183-192. DOI: 10.1515/johh-2015-0030.

CIGIZOGLU, H.K., BAYAZIT, M., ÖNÖZ, B. (2005): Trends in the maximum, mean, and low flows of Turkish rivers. Journal of Hydrometeorology, 6, 3, 280-290.

DIMKIĆ, D., DESPOTOVIĆ, J. (2012): Analysis of the changes of the streamflows in Serbia due to climate changes. Climate Change, 167-177.

GAUTAM, M.R., ACHARYA, K. (2012): Streamflow trends in Nepal. Hydrological Sciences Journal, 57, 2, 344-357. DOI: 10.1080/02626667.2011.637042.

GAVRILOV, M.B., MARKOVIĆ, S.B., JARAD, A., KORAĆ, V.M. (2015): The Analysis of Temperature Trends in Vojvodina (Serbia) from 1949 to 2006. Thermal Science, 19, S339-S350.

HANNAFORD, J., BUYS, G. (2012): Trends in seasonal river flow regimes in the UK. Journal of Hydrology, 475, 158-174. DOI: 10.1016/j.jhydrol.2012.09.044.

HIRSCH, R.M., SLACK, J.R., SMITH, R.A. (1982): Techniques of trend analysis for monthly water quality data. Water resources research, 18, 1, 107-121.

JIANG, Y., ZHOU, C., CHENG, W. (2007): Streamflow trends and hydrological response to climatic change in Tarim headwater basin. Journal of Geographical Sciences, 17, 1, 51-61. DOI: 10.1007/s11442-007-0051-8.

KENDALL, M.G. (1975): Rank Correlation Methods. Griffin, London, UK.

KORMANN, C., FRANCKE, T., RENNER, M., BRONSTERT, A. (2015): Attribution of high resolution streamflow trends in Western Austria-an approach based on climate and discharge station data. Hydrology and Earth System Sciences, 19, 3, 1225-1245. DOI:10.5194/hess-191225-2015.

KUNDZEWICZ, Z.W., ROBSON, A.J. (2004): Change detection in hydrological records a review of the methodology/revue méthodologique de la détection de changements dans les chroniques hydrologiques. Hydrological Sciences Journal, 49, 1, 7-19. DOI: 10.1623/ hysj.49.1.7.53993.

KUNDZEWICZ, Z.W., GRACZYK, D., MAURER, T., PIŃSKWAR, I., RADZIEJEWSKI, M., SVENSSON, C., SZWED, M. (2005): Trend detection in river flow series: 1. Annual maximum flow/Détection de tendancedans des séries de débit fluvial: 1. Débit maximum annuel. Hydrological Sciences Journal, 50, 5, 797-810. DOI: 10.1623/ hysj.2005.50.5.797. 
LINS, H.F., SLACK, J.R. (1999): Streamflow trends in the United States. Geophysical research letters, 26, 2, 227-230. DOI: 10.1029/1998GL900291.

LORENZO-LACRUZ, J., VICENTE-SERRANO, S.M., LÓPEZ-MORENO, J.I., MORÁN-TEJEDA, E., ZABALZA, J. (2012): Recent trends in Iberian streamflows (1945-2005). Journal of Hydrology, 414, 463-475.

LUTZ, S.R., MALLUCCI, S., DIAMANTINI, E., MAJONE, B., BELLIN, A., MERZ, R. (2016): Hydroclimatic and water quality trends across three Mediterranean river basins. Science of the Total Environment, 571, 1392-1406.

MANN, H.B. (1945): Nonparametric tests against trend. Econometrica, 13, 245-259.

MARTÍNEZ-FERNÁNDEZ, J., SÁNCHEZ, N., HERRERO-JIMÉNEZ, C.M. (2013): Recent trends in rivers with near-natural flow regime: The case of the river headwaters in Spain. Progress in Physical Geography, 37, 5, 685-700.

MASIH, I., UHLENBROOK, S., MASKEY, S., SMAKHTIN, V. (2011): Streamflow trends and climate linkages in the Zagros Mountains, Iran. Climatic Change, 104, 2, 317-338. DOI: 10.1007/s10584-009-9793-X.

NOVOTNY, E.V., STEFAN, H.G. (2007): Stream flow in Minnesota: indicator of climate change. Journal of Hydrology, 334, 3, 319-333.

PAKALIDOU, N., KARACOSTA, P. (2016): A 85-year-period study of extreme precipitation records in Thessaloniki (Greece). Acta Geobalcanica, 2, 2, 85-92. DOI:10.18509/AGB.2016.09.

PETRONE, K.C., HUGHES, J.D., VAN NIEL, T.G., SILBERSTEIN, R.P. (2010): Streamflow decline in southwestern Australia, 1950-2008. Geophysical Research Letters, 37, 11, L11401, DOI:10.1029/2010GL043102.

PETROW, T., MERZ, B. (2009): Trends in flood magnitude, frequency and seasonality in Germany in the period 1951-2002, Journal of Hydrology, 371, 1-4, 5, 129-141. DOI: 10.1016/j. jhydrol.2009.03.024.

RADEVSKI, I., GORIN, S. (2017): Floodplain analysis for different return periods of river Vardar in Tikvesh Valley (Republic of Macedonia). Carpathian Journal of Earth and Environmental Sciences, 12, 1, 179-187.

SEN, P.K. (1968): Estimates of the regression coefficient based on Kendall's tau. Journal of the American Statistical Association 63, 1379-1389.

STAHL, K., HISDAL, H., HANNAFORD, J., TALLAKSEN, L., VAN LANEN, H., SAUQUET, E., DEMUTH, S., FENDEKOVA, M., JORDAR, J. (2010): Streamflow trends in Europe: evidence from a dataset of near-natural catchments. Hydrology and Earth System Sciences, 14, 2367. DOI: 10.5194/hess-14-2367-2010.

SVENSSON, C., KUNDZEWICZ, W.Z., MAURER, T. (2005): Trend detection in river flow series: 2. Flood and low-flow index series / Détection de tendance dans des séries de débit fluvial: 2. Séries d'indices de crue et d'étiage. Hydrological Sciences Journal, 50, 5.

VASILESKI, D., RADEVSKI, I. (2014): Analysis of high waters on the Kriva Reka River, Macedonia. Acta Geographica Slovenica, 54, 2, 363-377. DOI: 10.3986/AGS54209.

YEH, C.F., WANG, J., YEH, H.F., LEE, C.H. (2015): Spatial and Temporal Streamflow Trends in Northern Taiwan. Water, 7, 2, 634-651. DOI:10.3390/w7020634.

YUE, S., PILON, P., PHINNEY, B., CAVADIAS, G. (2002): The influence of autocorrelation on the ability to detect trend in hydrological series. Hydrological Processes, 16, 9, 1807-1829. DOI: 10.1002/hyp.1095.

YUE, S., PILON, P., PHINNEY, B. (2003): Canadian streamflow trend detection: impacts of serial and cross-correlation. Hydrological Sciences Journal, 48, 1, 51-63. DOI: 10.1623/ hysj.48.1.51.43478. 
ZHANG, S., LU, X.X., HIGGITT, D.L., CHEN, C.T.A., HAN, J., SUN, H. (2008): Recent changes of water discharge and sediment load in the Zhujiang (Pearl River) Basin, China. Global and Planetary Change, 60, 3, 365-380. DOI: 10.1016/j.gloplacha.2007.04.003.

ZHANG, X., HARVEY, K.D., HOGG, W.D., YUZYK, T.R. (2001): Trends in Canadian streamflow. Water Resources Research, 37, 4, 987-998. DOI: 10.1029/2000WR900357.

ZHANG, X.S., AMIRTHANATHAN, G.E., BARI, M.A., LAUGESEN, R.M., SHIN, D., KENT, D. M., MACDONALD, A. M., TURNER, M.E., TUTEJA, N.K. (2016): How streamflow has changed across Australia since the 1950s: evidence from the network of hydrologic reference stations. Hydrology and Earth System Sciences, 20, 9, 3947-3965. DOI: 10.5194/hess-203947-2016. 